\title{
Active Learning based on Research for Linear Optimization Course at Department of Mathematics, Universitas Padjadjaran
}

\author{
Diah Chaerani ${ }^{1}$ and Stanley $P$ Dewanto ${ }^{2}$ \\ Department of Mathematics, Faculty of Mathematics and Natural Sciences \\ Universitas Padjadjaran \\ Jalan Raya Bandung Sumedang KM 21, Jatinangor 45363, Indonesia \\ d.chaerani@unpad.ac.id, ${ }^{2}$ stanleypd@bdg.centrin.net.id
}

\begin{abstract}
Linear Optimization (LO) course is one of the important courses in Industrial Mathematics (IM) and Operations Research (OR) field of applied mathematics. As the curricula now change into a competency based curricula, thus the instructional objective, course content, and approaches of teaching have to be improved. We refer to Cochran (2009) in evaluating our pedagogy in teaching Linear Optimization. At Department of Mathematics, Faculty of Mathematics and Natural Sciences, Universitas Padjadjaran Indonesia, especially for LO course, we plan to implement a student center learning using an active learning based on research for the coming academic year 2014/2015. Moazeni (2012) mentioned that, based on Liebman (1998), there are ten activities to promote active learning when teaching undergraduate OR courses, i.e., taxonomies, similarities and differences, forms and functions, advantages and disadvantages, type 1 frames, type 2 frames, concept mapping, metaphor and analogy, rehearsal, and advance organizer for instructor activity. These ten activities can be applied both in individual student activities in the classroom or group activities, in which case it is called as collaborative active learning. This collaborative active learning is recommended by Lasdon and Liebman (1998) to teach nonlinear programming. In this paper, we discuss how we adopt these ten activities in our teaching activity for the Linear Optimization course in our department. We also present how we introduce the students some results of our research on linear optimization application, i.e., in forestry tactical planning problem and vaccination strategy problem as real life example of the course applications.
\end{abstract}

Index Terms: Active Learning, Linear Optimization, Department of Mathematics Universitas Padjadjaran.

\section{Introduction}

Linear Optimization (LO) course is one of the important courses in Industrial Mathematics (IM) and Operations Research (OR) field of applied mathematics. As the curricula now change into a competency based curricula [1], thus the instructional objective, course content, and approaches of teaching have to be improved.

In this paper, we discuss how we design the activities for LO class using active learning. The use of this active learning is not new in operations research, as Ref. [4] noted in their paper, this learning approach is already used by Liebman 1998, Fellers 1996, and Meyers and Jones who have written books promoting the use of active learning in college classroom. As mentioned in Ref. [4], active learning can be cooperative when students work in groups. During the process, student teams solve problems and discuss theoretical issues during the class with instructors acting as facilitators.

In this paper, we discuss the situation in our Department of Mathematics, Faculty of Mathematics and Natural Sciences, Universitas Padjadjaran, in a goal to implement the use of active learning especially in LO course in which the first author becomes the lecturer for more than five years. The organization of the paper is as follows. In Section 2, we evaluate our pedagogy in teaching linear optimization. Section 3 discusses a learning design on a collaborative active learning for Linear Optimization course. A project based on research is presented in Section 3.3. We conclude this paper in Section 4.

\section{Evaluating our Pedagogy in teaching Linear Optimization}

As mentioned in Cochran [2], the operations research pedagogy is relatively static. Until approximately 1990, introductory operations research courses generally featured a heavy focus in the mathematical underpinnings of solutions algorithm for various classes of problems. In the early 1990s, a paradigm shift in operations research pedagogy slowly began to emerge.

Cochran [2] also stated that many instructors, who frustrated with traditional approaches to teaching introductory operations research, began developing courses that moved away from coverage of solution algorithms and instead focused squarely on applications. Classroom discussions began to deal more substantively with model building, interpretation of results, and implementation issues. Several operations research instructors contributed to this movement. Several instructors continue to successfully use traditional approaches and focus on solution algorithms, while those who have adopted nontraditional approaches have moved in diverse directions. As one reflects on new approaches that have been adopted by these instructors, it is constructive to consider specific ways operations research instructors have changed their approaches and their possible motivations in making these changes.

Briefly, we present in Figure 1 data on the number of students of our Department Mathematics, Faculty of Mathematics and Natural Sciences, Universitas Padjadjaran, 
who are interested in industrial mathematics and has to take a compulsory course Linear Optimization. As we can see in Figure 1, the trend of students' number who chooses this field relatively increases each year.

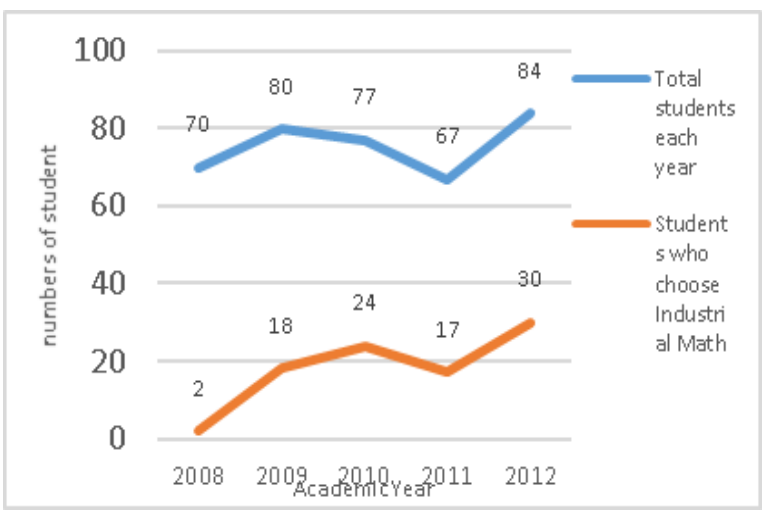

Figure 1. The number of students who are interested in Industrial Mathematics (2008-2012)

The students' achievement in marks can be seen in Figure 2. In four sessions of LO lectures, we can see the average percentage of marks A, B, C, D, E in Figure 3.

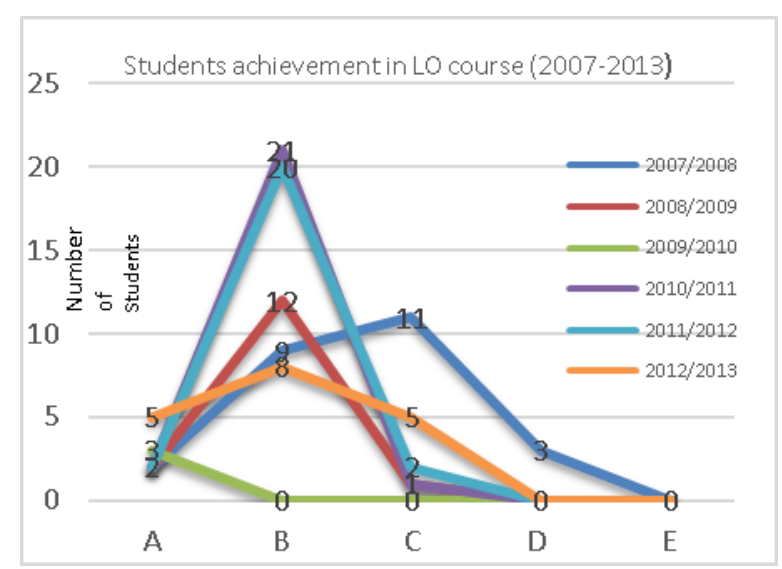

Figure 2. Students achievement in LO Courses (2007-2013)

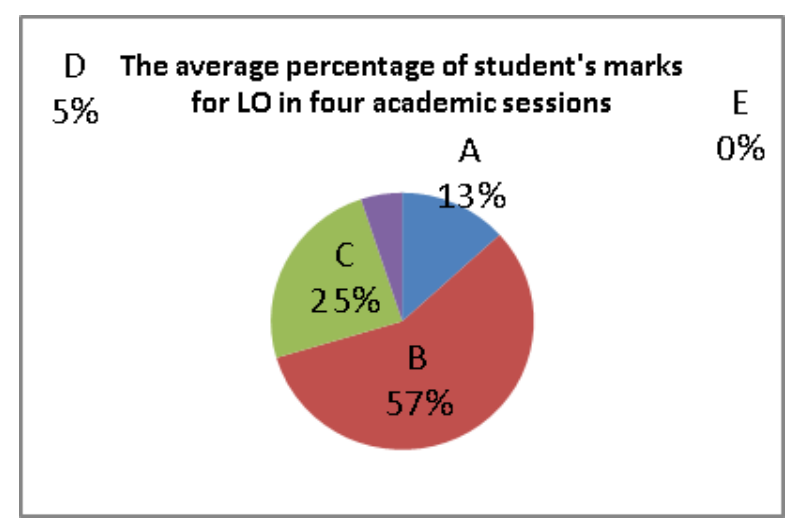

Figure 3. The average percentage of students' marks for LO in 4 academic sessions

As we can see in Figures 2 and 3, the students' achievement is quite good and no student has failed the course. Unfortunately, in a succeeding courses in the following semester after the LO, the students showed a low understanding of LO course. This fact drove the first author to evaluate the pedagogy on LO course and conclude to change the pedagogy to a collaborative active learning.

\section{A learning design on a collaborative active learning for Linear Optimization course}

At Department of Mathematics, Faculty of Mathematics and Natural Sciences, Universitas Padjadjaran Indonesia, especially for LO course, we plan to implement a student center learning using an active learning based on research for the coming academic year 2014/2015.

This collaborative active learning is recommended by Lasdon and Liebman [4] to teach nonlinear programming. In this paper, we discuss how we adopted these ten activities in our teaching activity for the Linear Optimization course in our department. Moazeni [3] mentioned that, based on Liebman (1998), there are ten activities to promote active learning when teaching undergraduate OR courses, i.e., taxonomies, similarities and differences, forms and functions, advantages and disadvantages, type 1 frames, type 2 frames, concept mapping, metaphor and analogy, rehearsal, and advance organizer for instructor activity.

In the undergraduate course, as it is discussed in Ref. [4], Liebman first used active learning techniques when she taught two sections of the course simultaneously. One section used learning groups and had no lectures, and the other sections had lectures with cooperative active learning only through turn-to-your neighbor discussions every 10 to 12 minutes. We adopted those methods of learning groups and had no lecturers, and the other section had lectures with cooperative active learning, to our LO class.

\subsection{Student Activity}

For LO course at our department, the tasks are listed based on the topics of LO that can be seen in Table 1. The textbook that we used for this undergraduate LO course is Refs. [7] and [8]. The students are expected to do the following in groups:

a) Know the mathematical form of a general LO problem.

b) Understand the following examples of LO models: the prototype example that pose in Ref. [7], i,e, determine what the production rates should be for the two products in order to maximize their total profit, subject to the restrictions imposed by the limited production capacities available in the a number of plants.

c) Be able to develop a mathematical model for a $\mathrm{LO}$ problem described in words.

d) Know the definitions of decision variable, objective function, constraints function, data parameter, standard and canonic form, basic feasible solution and how to convert the problem into a simplex tableau.

e) Know how to use the simplex method to solve the LO model.

f) Know to detect the infeasibility condition, the unbounded condition, degeneracy solution, cycle condition and the condition when an infinite number of solution will happens. 
g) Know how to use excel, Maple or Matlab to solve LP problems.

Table 1. Topics each week based on Refs. [7] and [8]

\begin{tabular}{|l|c|}
\hline \multicolumn{1}{|c|}{ Topic } & Week \\
\hline Motivation to LO & 1 \\
\hline Introduction to LO & 2 \\
\hline Algebra for LO & 3 \\
\hline Simplex Method & 4,5 \\
\hline Big-M Simplex Method & 6, \\
\hline Two phase simplex method & 7 \\
\hline Revised Simplex & 8 \\
\hline Duality in LO and Dual Simplex Method & 9,10 \\
\hline Decomposition principle & 11 \\
\hline Sensitivity analysis and post optimal & 12,13 \\
\hline Transportation Problem & 14 \\
\hline Assignment Problem & 15 \\
\hline
\end{tabular}

The following is how we define tasks for students in groups using active learning only through turn-to-your neighbor discussions every 10 to 12 minutes.

a) Taxonomies; students are asked to develop a taxonomy for optimization model.

b) To define the similarities and differences for LO, we design assignment on listing the similarities between model linear programming via simplex methods, bigM, simplex two phases, dual simplex.

c) To do activity on knowing forms and functions of LP, the students will be asked to explain the role of constraints in linear optimization model.

d) Students need to know about advantages and disadvantages of the LO methods, thus students will be asked to explain advantages of solving a (infeasible) linear optimization model via big-M, two phases, dual simplex,

e) Students make the type 1 frames (e.g. fill in the cells of a table whose rows represent different linear optimization algorithm and columns are labeled initialization, determining direction of movement and termination criteria),

f) Students make the type 2 frames (e.g. fill in the missing steps of a proof a fundamental theorem of linear optimization),

g) The concept mapping of LO e.g. develop a hierarchy map representing the categorical relationship of linear optimization algorithm must be achieved by students in group.

h) Use a metaphor and analogy to compare and extent the simplex method to revised simplex methods,

i) Do some rehearsal e.g. use the simplex method on an transportation, assignment problem,

j) For the lecture, an advanced organizer for instructor activity must be done

\subsection{Lecture activity}

In this active learning, the one expected to be more active is the students, thus the lecture will change the activity from lecture the subject to group discussion. The students are first divided into groups of three or four and then they will work in a group to determine each activity. Each week there will be one group who will present their work which is selected randomly. We aim that all groups must do all the activities and all groups must be ready any time to present their work.

\subsection{Project based on Research}

We also present how we introduce the students to some results of our research on linear optimization application, i.e., in forestry tactical planning problem [5] and vaccination strategy problem [6] as real life example of the course applications. From both problems, we expect that the students can define (in both problems) decision variables, objective and constraints functions. Solve a small example pusing excel, Maple or Matlab.

\section{Project 1}

We introduce the results of our research in modeling vaccination strategy problem via Interior Point Methods [6]. We will ask students to present this problem in the class discussion.

The problem that students have to solve is the problem of vaccination strategy linear optimization model as proposed by Becker and Starczak [9], with objective function to minimize vaccination coverage subject to the basic reproduction number must keep stays between 0 and 1 and the total proportion of family member who has been vaccinated is equal to 1 . Within this project students are asked to define the case with 2,3,4,5 households with various numbers of members of the family, and try to solve the problem.

\section{Project 2}

The tactical planning of forestry industry based on clean development mechanism [5] is also considered as the second project.

The problem can be formulated as follows: minimized the operations and transportation cost of cutting off the forest, and delivering from forest to the customer. The problem consists of some assignment problems, which is for a number of crews there is only one subforest that can be cut in one time period. The problem is considered can be solved using Hungarian Methods. The students will be asked to define the conditions of transportation and assignment problem, ask must solve it using transportation simplex method and also Hungarian method.

All groups of students must prepare the presentation and have to be ready whenever the instructor asks them to present.

\section{Conclusion}

Active learning is one of pedagogy technique that can be implemented to LO course. The targeted learning outcome is defined above. As the future research topic, we need to investigate how the result of this active learning at our department is. Furthermore, what suggested by Ref. [10] is also interesting to be adopted in the class of LO. 


\section{Acknowledgment}

Part of this research was funded by DIPA Universitas Padjadjaran under the program Penelitian Unggulan Perguruan Tinggi (PUPT) for the year of 2014 with contract number 304/UND.6/PL/2014.

\section{References}

[1] Peraturan Menteri Pendidikan dan Kebudayaan Republik Indonesia tentang Standar Nasional Pendidikan Tinggi, Nomor 49 Tahun 2014.

[2] J. Cochran, "Pedagogy in operations research: Where has the discipline been, where is it now, and where should it be?," ORiON, vol. 25, no. 2, pp. 161-184, 2009.

[3] S. Moazeni, "Effective strategies to teach operations research to nonmathematics majors," 12 July 2012. [Online]. Available: http://www.optimization-online.org/DB_HTML/2012/07/3548.html. [Accessed 5 June 2014].

[4] L. Lasdon, J.S Liebman, "The teacher's forum: Teaching nonlinear programming using cooperative active learning," INTERFACES, vol. 28, no. 4, pp. 119-132, 1998.

[5] D. Chaerani, Sudradjat, Firdaniza, E. Kurniadi, "Penentuan model dan design robust untuk masalah perencanaan taktis industri kehutanan berbasis clean development mechanism," Laporan Akhir Penelitian, Lembaga Penelitian dan Pengabdian kepada Masyarakat Univesitas Padjadjaran, Sumedang, 2012.

[6] D. Chaerani, A. Anisah, N. Anggriani, Firdaniza, "Minimizing Linear Optimization Model of Basic Reproduction Number in a Fixed Number of Vaccination Coverage using Interior Point Method Approach," in Proceedings of International Seminar on Sciences (ISS) 2013, Institut Pertanian Bogor, Bogor Indonesia, ISBN 978-97995093-9-0, pp 235-240, Mei 2014.

[7] F. S. Hillier and G. J. Lieberman, Introduction to Operations Research (9th edition), McGraw-Hill, ISBN 978-007-126767-0., 2010.

[8] S. Rao, Optimization: Theory and Application, New Delhi: PrenticeHall, 1989.

[9] N. G. Becker and D. N. Starczak, "Optimal vaccination strategies for a community of households," Math. Biosci., vol. 139, no. 2, p. 117 , 1997.

[10] N. Devia and R. Weber, "Actice learning exercise: Newspaper page layout," INFORMS Transactions on Education, vol. 12, no. 3, pp. 153156, 2012. 